auxiliary materials, fabrics and accessories that are not produced or not produced in the Republic, and used in the manufacturing process of the finished product;

- shall be exempt from the payment of customs duties on components, raw materials and materials not only enterprise specializing in the production of non-food consumer goods, but also other importers.

This will contribute to the development of the internal market of the product and reduce the cost of textile enterprises.

\title{
References:
}

1. Madjidov Sh., Khakimov B. Viewpoints about potential stimulation and possibilities of investments on textile industry Uzbekistan.//European journal of business and economics. - Volume 6. - 2012. - P. 22-24//[Electronic resource]. - Available from: http://ojs.journals.cz>index.php/EJBE/article/view/138.

2. Madjidov Sh., Khakimov B. About investment condition of silk branch.//European Applied Sciences. Journal. ORT Publishing. - Shtutgart, Germany. - 2014. - No. 7.

3. Investment program of the State Joint stock company «Uzbek light industry», 2015-2019.

4. Uzbekistan in figures 2010-2013. Statistical compendium. The state statistics Committee of Uzbekistan. - Tashkent, 2011-2014.

5. [Electronic resource]. - Available from: htpp://www.legprom.uz.

Muminova Nargiza, department of "Management", Tashkent institute of textile and light industry E-mail:shohruh1983@bk.ru

\section{Segmental analysis of the market potential of the textile industry of Uzbekistan}

\begin{abstract}
In this article, on the basis of the conducted marketing research studied the possibility of increasing the export potential of the textile industry.

Keywords: segment, market, export, textile industry, textile product.

Introduction: the Textile industry is not only industry that produces non-food consumer goods for the population, but also has a social dimension, as it promotes the creation of new jobs. With the development of the textile industry in Uzbekistan hopes for a solution to many economic and social problems. This fact makes this industry a relevant object for opportunistic marketing research. Textiles for Uzbekistan has a special meaning.

Analysis: Marketing analysis of the market potential of the textile industry involves the study of market structure to identify unreached segments and search marketing capabilities.

The main objective of this review is to present the material, sufficient to confirm the assumption that the proposed product is a steady demand and can be implemented in terms of competition.

There are many options analysis of market potential with different numbers of stages and different content of these stages. Selection of the best option is made based on the nature of the tasks and characteristics of consumer

demand and market competition. The standard algorithm of market analysis usually consists of several stages, which can be implemented in different orders [1]:

1. Product detail - involves a description of the scope of application of the product, its consumer properties and features. The analysis of these parameters is in table form on the basis of objective parameters (weight, price, properties, etc.) or through the assessment in nominal scale (point system).

2. The definition of market capacity - involves a description of the target groups of consumers (type, need, area), the degree of saturation of the market and assessment of effective demand. As sources of information used data from the state statistics, consulting organizations and Resellers, as well as the method of observation.

3. A competitive analysis involves the analysis of marketing strategies and tactics of competitors, explored the occupied proportion of the target market. The analysis of these parameters is carried out in tabular form by quantitative (in national currency, items, etc.) or qualitative (in percent) evaluation.
\end{abstract}


4. Definition of product boundaries of the market implies the calculation of the market shares of goods versus goods (analogs and substitutes) competitors. Is determined according to government statistics, consulting organizations, etc.

5. The definition of the geographical boundaries of the market - involves the analysis of the sphere of influence of potential marketing infrastructure. Knowing this sphere of influence, by process of elimination you can determine that part of the market that is not covered by the existing infrastructure markets. As information used external sources and internal statistics of the company.

The most important result of the analysis of the potential expansion of the market niche textile enterprises is market segmentation the identification of target segments and the development of marketing mix and marketing strategies. The main goal is the optimal location of retail outlets on two main criteria: "proximity" and "fame".

Therefore, firstly, segmentation is a strategy used by the seller for the concentration of resources in the target market and optimize their use. Secondly, segmentation is the procedure of analyzing the market seller for the best considering its features.

We should distinguish two concepts:

1. Signs of market segmentation is highlighted consumers behaviour, by which we can judge that the market lends itself to segmentation. Such symptoms can be many, but underlying them all is one - the presence of imbalances in the demand in the market.

2. Criteria of market segmentation is the criteria by which many market participants are allocated to the target audience. Such criteria also can be many, but they all focused on the needs of potential buyers.

Effectively carried out segmentation simplifies and reduces the cost of marketing policy, eliminates many costly methods of promotion. The explanation is very simple. The buyer comes to the seller for advertising and discounts, as for the satisfaction of their needs. So sellers offering products that better meet the needs buyers (properties, quality, price, etc.), can achieve better effect, and also to minimize the cost of advertising and discounts.

The market segmentation is to identify unmet customer needs and time to offer the target groups of buyers. Market segmentation is conducted to identify target markets, requiring the development of specific strategies to promote products that are unique to the organization infrastructure and sales promotion. When performing any segmentation market environment can be represented as a sum of four main components:

- consumers, as carriers of unmet effective demand;

- contractors, as partners in joint promotion of products on the market;

- competitors, as an alternative to consumer demand;

- suppliers, as a primary source of economic activity in the market.

All of these actors have a decisive influence on the marketing of products and at the same time themselves amenable to segmentation. Therefore, the analysis of potential extensions is advisable to carry out a market niche in four directions:

- Segmentation of consumers. The segment of the consumer market is consumers with similar preferences in the choice of goods and reacting to similar activities to create demand.

- Segmentation contractors. Segment of the market contractors is a channel of marketing. Its attractiveness is determined by the throughput and coverage consumers. Counterparts are the middlemen who for remuneration perform functions relating to the promotion of goods on the market that the seller is not willing or able to do yourself.

- Segmentation competitors. Competitors characterize the market for the products. Their competitiveness is directly related to the life cycle of the product and the market. Competitor activity is an indicator of loss of market opportunities for the company. It follows a simple algorithm for segmenting competitors through analysis of market opportunities.

- Segmenting suppliers. Suppliers define basic component of marketing activities - costs. On suppliers marketing activities are extended to the same extent as other participants in the marketing environment of an enterprise. These are two sides of the same coin: you can get profits by increasing the sale of goods, but you can by saving on total costs. The main parameters of the segmentation market: the relevance of the chosen segment; the quantitative parameters of the segment (market niche, capacity); the competitiveness of the product in the chosen segment (positions, image); the complexity of development of the chosen segment; the quantitative parameters of sales in the segment (profitability and cost); prospects of the chosen segment, etc [4].

The size of the target market, occupied as a result of successful segmentation is a key indicator of marketing activities.

Analysis of market opportunities and segmentation will identify methods of influence on the demand and 
potential sales through motives of market participants and their purchasing (bandwidth) capacity. This is the fundamental part of marketing activities, its internal component, which determines directly the parameters of the material flows in the process of marketing activity of the enterprises of the textile industry.

As a result of market research in the textile industry appeared unlimited opportunities to gain the leading position in the world textile export market of textile products especially finished products. In the structure of exports of textile products in 2014 the share of yarn is $58 \%$; the finished product $-25 \%$; fabric $-7 \%$; knitted fabric $-5.2 \%$ and the production of silk is $2.8 \%$ [2].

Exports textile enterprises of the Republic has increased significantly not only volumes, but also increased the number of exported countries as well as exporters of total exports, for example, if in 2013 the share of new exporters was $5.3 \%$, while in 2014 this figure is expected to reach 8.4 per cent. For the period from 2011 by 2013 , the number of exporters has increased from 123 to 250 companies. If the rate of growth of exports in 2010 amounted to $160 \%$, in 2013 amounted to $183 \%$ [3].
In the period 2013-2014, exploited markets of 48 countries, including 5 new market, Hungary, Sri Lanka, Kenya, Morocco and Tunisia. Also mastered such remote countries as Argentina, Brazil, Venezuela, Colombia, Peru, Chile, and South Africa. Currently the company has created more than 60 dealer units exporters in the EU, CIS and Asia [5].

Conclusion: In our opinion, the organization of marketing activities in enterprises of the textile industry should be based on the following activities:

- building an organizational structure marketing management;

- selection of marketing professionals who are duly qualified;

- creation of conditions for effective work of employees of the marketing department;

- organization of effective interaction of marketing with other services companies.

Thus, the organization of marketing activities for the above described activities will enable the textile industry to improve production efficiency and be able to maintain its position in the commodity market.

\title{
References:
}

1. Muminova N. Stimulation of demand competitive textile products.//Federation Journal. Russia. - 2014. - No. 1-2.

2. Madjidov Sh., Khakimov B. Viewpoints about potential stimulation and possibilities of investments on textile industry of Uzbekistan.//European journal of business and economics. - Volume 6. - 2012. - P. 22-24.

3. Madjidov Sh., Khakimov B. About investment condition of silk branch.//European Applied Sciences. Journal. Shtutgart, Germany: ORT Publishing, - 2014. - No. 7.

4. Muminova N. The objectives of the development of marketing services in the trade of textile products. The monograph “IQTISOD va MOLIYA". - Tashkent, 2013. - 200 p.

5. [Electronic resource]. - Available from: htpp://www.legprom.uz.

Starkova Nadezhda Olegovna,

Kuban State University,

candidate of science in Economics, associate professor, International economics

and management department

E-mail:n.starkova@mail.ru

Buchina Elena Vasilievna,

Kuban State University,

undergraduate of International economics

and management department

E-mail:korolevi4na90@mail.ru

\section{Features of forming of brand of Krasnodar Region}

\begin{abstract}
Rising role of branding of territories in management of socio-economic development of regions has been estimated. Most favorable conditions for the formation of an effective brand in the region have been determined. Unique advantages of Krasnodar region, as one of most promising and attractive for tourists, businessmen
\end{abstract}

